\title{
Indoor Airborne Microbial Burden of Operating Theatres in a Tertiary Hospital in South-Western Nigeria
}

\author{
O. Ogundare Johnson', G. Fakunle Adekunle ${ }^{2 *}$, Alege Adenike ${ }^{3}$, T. Soyemi Elizabeth ${ }^{4}$, \\ M. Ezinne Sylvia ${ }^{1,3}$ and M. Bolaji Olayinka ${ }^{1,3}$ \\ ${ }^{1}$ Department of Clinical Nursing, University College Hospital, Ibadan, Nigeria \\ ${ }^{2}$ Blue Gate Public Health Promotion Initiative, Ibadan, Nigeria \\ ${ }^{3}$ Department of Environmental Health Sciences, Faculty of Public Health, University of Ibadan, \\ Ibadan, Nigeria \\ ${ }^{4}$ Department of Microbiology and Parasitology, University College Hospital, Ibadan, Nigeria \\ *Corresponding author
}

A B S T R A C T

\begin{abstract}
Keywords
Microbial burden, Operating theater, Surgery, Tertiary hospital, Nigeria.

Article Info

Accepted:

10 July 2017

Available Online:

10 September 2017 threatening nosocomial infections for patients undergoing certain surgical procedures. There is dearth of information on the burden of airborne microbial contaminations of operating theatres in this environment, hence the need for the study. The study aimed at investigating the airborne microbial load and type of pathogenic isolates as a result of surgical procedures in the operating theatres of a tertiary hospital in South-west Nigeria. A purposive selection of seven operating theatres was adopted for this study. Airborne microbial samples were collected using gravitational method and the total bacterial counts (TBC) and total fungal counts (TFC) per cubic-metre were determined before and after surgery. Indoor TBC and TFC after surgery $\left(2.1 \times 102 \mathrm{cfu} / \mathrm{m}^{3}\right.$ and $\left.0.17 \times 102 \mathrm{cfu} / \mathrm{m}^{3}\right)$ was significantly higher than before surgery $\left(0.5 \times 102 \mathrm{cfu} / \mathrm{m}^{3}\right.$ and $\left.0.03 \times 102 \mathrm{cfu} / \mathrm{m}^{3}\right)$ and the fisher's index. Staphylococcus spp. and Aspergillus spp. were one of the bacteria and fungi species isolated respectively. The study implicated the indoor environment of the operating theatres as a source of contamination.
\end{abstract}

Indoor air contamination of the operating theatres is one of the major sources of life

\section{Introduction}

Airborne microbial contamination of the indoor air environment of operating theatres (OT) is one of the risk factors for the development of post-surgical Infections (PSI) and had contributed to increased prevalence of nosocomial infections (NIs) (Al-Benna, 2012; Fleischer et al., 2005; Ensayel et al., 2009; Okon et al., 2012). About 10\% of hospital acquired infections result in increased patient mortality, morbidity and length of hospital stay in addition to the overall costs of hospital admissions for post-operative surgery (Chacko et al., 2003; Reddy, 2012),Multiple sources have been previously reported as being associated with the contamination of the OT, including drainage of the wounds, ventilation systems, transportation of patients and collection bags, surgical team, degree of indoor traffic, theatre gown, foot wares, gloves, use of inadequately sterilized equipment and grossly contaminated surfaces(Okon et al., 2012; Fleischer et al., 
2005). The impact of these individual sources on the level of microbial contamination differs, depending on the numbers of pathogens involved. Major pathogens associated with infection of surgical devices include Staphylococcus aureus and coagulase negative staphylococci (CoNS) (Edmiston et al., 2005).

In order to achieve adequate infection control practices of an OT, the prevention of microbial contamination is of utmost importance.

According to Fleischer et al., 2005, the reduction of airborne bacteria in the OT by about 13-fold would reduce wound contamination after surgery by about $50 \%$. This reduction in wound contamination after surgry depends primarily on improving cleaning, proper disinfection and regular fumigation of the OT (Okon et al., 2012; Chacko et al., 2003; Fleischer et al., 2005).

Studies carried out in Nigeria and other countries on indoor and outdoor air quality of hospital environment have identified specific microorganisms responsible for certain infections. Some of the microorganisms identified contains spores and can withstand different conditions thereby making them resistant (Odimayo et al., 2008; Prigane et al., 2004).

Some other studies have investigated microbial contamination from fomites as sources of contamination in operating theatres in North-western Nigeria (Nwankwo and Azeez, 2015) with the aim of promoting efficient infection control but the burden of airborne contamination in operating theatres remains unknown. Therefore, this study aimed at investigating the level of indoor airborne contamination and types of pathogenic bacteria and fungi in the operating theatres of a tertiary hospital in South-west Nigeria.

\section{Materials and Methods}

\section{Study area}

This study was carried out in seven (7) operating theatre of a tertiary hospital situated in South-western region of Nigeria between January and April, 2014.The tertiary hospital was established in response to the need for the training of medical personnel and other healthcare professionals for the country and the West African Sub-Region. The hospital was commissioned with 500 bed spaces but presently it has 850 bed spaces and 163 examination couches, The current bed occupancy ranges from 55-60\%.

\section{Study sites}

The study focuses on major active Operating Theatre Units in the surgery department of the hospital consisting of: Main Operating theatre (with 5- Vamed Operating suites; T1 - T5), Gynaecological Operating Theatre (with 1Operating suite; T6) and the Emergency Operating Theatre (with 1- Operating suite; T7).

\section{Meteorological parameters and airborne microbial sampling}

Indoor and outdoor temperature $\left({ }^{\circ} \mathrm{C}\right)$ and relative humidity $(\%)$ of the OTs were measured using a 5-in-1 multi-tester N21FR made in China and values obtained were compared with the Association of Peri Operative Registered Nurses (AORN) (AORN, 2010) guideline limit for temperature (20 $\left.24^{\circ} \mathrm{C}\right)$ and relative humidity $(20-60 \%)$. The met-one particle counter was used to measure the concentration of particulate matter $\left(\mathrm{PM}_{10}\right)$ in the indoor and outdoor environment of the OTs. The ambient and indoor measurements were determined at two periods of the day "Before Surgery" (6am-7am) and "After Surgery" (2pm-5pm) for the entire study period. 
PM Concentration $\left(\mu \mathrm{g} / \mathrm{m}^{3}\right)=$ Number of Particles $\times 3531.5 \times$ particle mass.........equation 1

Where the mass of a particle in the $P M_{10}$ channel is 1.21E-4 $\mu \mathrm{g}$

Indoor and outdoor air samples were collected using gravitational method for a duration of 10 minutes. The individual microbiological agents were trapped by exposing sterile prepared Petri dishes containing Nutrient agar (NA) and Potatoes Dextrose agar (PDA) to the indoor and outdoor air environments. All samples were collected during the day at about $1.5 \mathrm{~m}$ above the ground at the centre of the room for indoor air samples and at least $2 \mathrm{~m}$ away from the building for outdoor samples (Mentes et al., 2009). Incubation of NA plates was carried out at $35^{\circ} \mathrm{C}$ for 48 hours while PDA plates were incubated at room temperatures for five days prior to counting. Pure cultures of the individual organisms were stored on agar slant inside the refrigerator at $4^{\circ} \mathrm{C}$.Sampling was conducted during the dry season.

\section{Determination of airborne microbial concentration and identification}

The concentration of airborne bacteria and fungi in the OTs was determined according to Polish Standard PN 89/Z-04008/08. The total colony forming units (cfu) per plate was read and converted to colony forming units per cubic metre $\left(\mathrm{cfu} / \mathrm{m}^{3}\right)$. The number of $\mathrm{cfu} / \mathrm{m}^{3}$ was estimated according to the equation below:

$\mathrm{cfu} / \mathrm{m}^{3}=\mathrm{a} * 10,000 / \mathrm{p} * \mathrm{t} * 0.2$ .........................equation 2

Where $a$ is the number of colonies on the Petri plate, $p$ the surface of the Petri plate (cubic meter) and $t$ the time of Petri plate exposure (seconds).
The identification of isolated bacteria was based primarily on morphology, gram staining, growth characteristic, culture characteristics and biochemical tests. Bacteria which are normal flora of the indoor and outdoor air were identified to the genus level by comparing with Bergey's manual of systematic bacteriology (Holt, 1994). Light microscope was used to determine the colony features and the morphological structures of the fungi.

\section{Statistical analysis}

Descriptive statistics (proportion, means, standard deviation and frequency tables) was used to summarize the data. Analyses were conducted using SPSS software version 15 (IBM SPSS Statistics). T-test was used to compare mean differences of total bacterial count (TBC) and total fungal count (TFC) and other environmental parameters before and after surgery. Spearman's correlation analyses were carried out to determine the level of relationships between environmental parameters, TBC and TFC.

\section{Results and Discussion}

\section{Indoor Environmental Condition of the Operating theatres (OTs)}

The indoor and outdoor assessment of the OTs showed that mean indoor temperature $\left(31.3 \pm 2.1^{\circ} \mathrm{C}\right)$ and relative humidity $\mathrm{RH}(74.3$ $\pm 6.35 \%$ ) after surgery were higher than the values obtained before surgery $\left(28.1 \pm 2.0^{\circ} \mathrm{C}\right.$ and $59.7 \pm 4.8 \%$ ) and the AORN limit of $27.0^{\circ} \mathrm{C}$ and $60.0 \%$ respectively $(\mathrm{p}<0.05)$. Similarly, mean outdoor temperature and relative humidity $(\mathrm{RH})$ readings after surgery was $30.3 \pm 1.4^{\circ} \mathrm{C}$ and $72.5 \pm 6.8 \%$ as compared to $27.4 \pm 1.4^{\circ} \mathrm{C}$ and $56.7 \pm 4.1 \%$ before surgery $(\mathrm{p}<0.05)$. The mean indoor and outdoor $\mathrm{PM}_{10}$ after surgery (2560.1 \pm $631.5 \mathrm{ppm}$ and $2943.1 \pm 701.6 \mathrm{ppm})$ were 
higher than values obtained before surgery $(1862.9 \pm 613.5 \mathrm{ppm}$ and $2047.6 \pm 613.5 \mathrm{ppm})$ respectively (as shown in table $1-3$ ). Figures $1-3$ revealed the trend in mean temperature, relative humidity and $\mathrm{PM}_{10}$ concentration across the 12 weeks' study period compared to the AORN standard. The mean indoor/outdoor measurements of $\mathrm{PM}_{10}$ were found to be higher than the AORN standard.

\section{Airborne microbial burden before and after surgery}

Figure 5 revealed that the mean indoor TBC after surgery $\left(1.217 \times 10^{2} \mathrm{cfu} / \mathrm{m}^{3}\right)$ was higher than values obtained before surgery $\left(0.51 \times 10^{2} \mathrm{cfu} / \mathrm{m}^{3}\right) \quad \mathrm{p}<0.05$. Similarly, a significant difference in the mean indoor TFC after surgery $\left(0.126 \times 10^{2} \mathrm{cfu} / \mathrm{m}^{3}\right)$ and before surgery $\left(0.046 \times 10^{2} \mathrm{cfu} / \mathrm{m}^{3}\right)$ was recorded. The Emergency operating theatre (T7) recorded the highest mean indoor TBC $\left(1.448 \times 10^{2} \mathrm{cfu} / \mathrm{m}^{3}\right)$ and TFC $\left(0.139 \times 10^{2} \mathrm{cfu} / \mathrm{m}^{3}\right)$ when compared to other operating theaters (see Figures 6 and 7 for details). A significant difference was obtained in the mean outdoor TBC and TFC before surgery $\left(0.29 \times 10^{2} \mathrm{cfu} / \mathrm{m}^{3}\right.$ and $\left.0.015 \times 10^{2}\right)$ and after surgery $\left(1.16 \times 10^{2} \mathrm{cfu} / \mathrm{m}^{3}\right.$ and $\left.0.042 \times 10^{2}\right)$ respectively.

\section{Spearman's correlation of airborne microbial count and environmental parameters}

Table 4 showed the relationship between environmental parameters measured and the microbial load using spearman's rank correlation. The indoor air RH was strongly correlated with both indoor TBC ( $\mathrm{rs}=0.742$ ) and indoor TFC (rs $=0.722$ ). Similarly, a strong correlation was observed between Indoor air Temperature and indoor TBC ( $\mathrm{rs}=$ $0.60)$. A moderately positive correlation was also observed between indoor $\mathrm{PM}_{10}$ versus indoor TBC ( $\mathrm{rs}=0.471)$ and indoor PM versus indoor TFC ( $\mathrm{rs}=0.504)$.

Profile of airborne microbial isolates in operating theatres before and after surgery

Identification of bacterial isolates revealed that Staphylococcus spp. was the most common isolate bacteria before $(21.5 \%)$ and after surgery (38.1\%), followed by Streptococcus spp. (18.4\% and 26.6\%). Bacillus spp. $(14.2 \%, 19.5 \%)$ and Pseudomonas spp. $(8 \%, 10.6 \%)$ were among bacteria species isolated from the operating theatres before and after surgery respectively. The dominant fungal species was found to be Aspergillus spp. $26.5 \%$ (before surgery) and $36.3 \%$ (after surgery). Penicillium spp. (20.4\%, 29.5\%), and Candida spp. (16.4\%, $21.4 \%$ ) were among fungi species isolated from the operating theatres before and after surgery respectively.

In the indoor environment of an operating theatres, the indoor air temperature is affected by certain factors such as the outdoorair temperature and the efficiency of mechanical ventilation system in the hospital (Godish, 2003).The absorption of moisture by building materials results in a high relative humidity levels which directly support microbial growth and increase the settling rate of aerosols. The Association of Operating Room Nurses (AORN) recommends acceptable ranges of indoor air temperature and relative humidity for an operating theatre to be $20^{\circ} \mathrm{C}$ $27^{\circ} \mathrm{C}$ and $30 \%-60 \%$ respectively. The mean indoor air temperature and relative humidity after and before surgery were found to be higher than the AORN acceptable limit which reflect an inefficient system of ventilation in the operating rooms. 
Table.1 Mean indoor air temperature of OTs before and after surgery

\begin{tabular}{cccccc}
\hline Period of Surgery & $\mathbf{N}(\%)$ & \multicolumn{3}{c}{ indoor air temperature $\left({ }^{\circ} \mathbf{C}\right)$} & P value \\
\cline { 3 - 5 } & & Minimum & Maximum & Mean \pm SD & \\
Before & $252(100 \%)$ & 26.0 & 29.0 & $28.1 \pm 2.0$ & 0.00 \\
After & $252(100 \%)$ & 29.0 & 33.0 & $31.3 \pm 2.1$ & \\
\hline
\end{tabular}

Table.2 Mean indoor air relative humidity (RH) of OTs before and after surgery

\begin{tabular}{cccccc}
\hline Period of Surgery & N (\%) & \multicolumn{3}{c}{ IRH (\%) } & P value \\
\cline { 3 - 5 } & & Minimum & Maximum & Mean \pm SD & \\
Before & $252(100 \%)$ & 52.0 & 59.3 & $59.7 \pm 4.8$ & 0.00 \\
After & $252(100 \%)$ & 65.4 & 81.0 & $74.3 \pm 6.3$ & \\
\hline
\end{tabular}

Table.3 Mean indoor air Particulate matter size 10 micron $\left(\mathrm{PM}_{10}\right)$ of

OTs before and after surgery

\begin{tabular}{cccccc}
\hline Period of Surgery & N (\%) & \multicolumn{3}{c}{ IPM $_{\mathbf{1 0}}(\mathbf{p p m})$} & P value \\
\cline { 3 - 5 } & & Minimum & Maximum & Mean \pm SD & \\
Before & $252(100 \%)$ & 1123.0 & 2934.0 & $1862.9 \pm 634.4$ & 0.00 \\
After & $252(100 \%)$ & 2132.0 & 3967.0 & $2560.1 \pm 631.5$ & \\
\hline
\end{tabular}

Table.4 Relationship between Indoor environmental parameters and airborne microbial burden using Spearmans' Rank Correlation

\begin{tabular}{|c|c|c|c|c|c|}
\hline Variable & $\begin{array}{l}\text { Indoor air } \\
\text { Temp }\end{array}$ & $\begin{array}{l}\text { Indoor air } \\
\text { RH }\end{array}$ & $\begin{array}{l}\text { Indoor air } \\
\mathrm{PM}_{10}\end{array}$ & $\begin{array}{l}\text { Indoor air } \\
\text { TBC }\end{array}$ & $\begin{array}{l}\text { Indoor air } \\
\text { TFC }\end{array}$ \\
\hline $\begin{array}{l}\text { Indoor air } \\
\text { Temp }\end{array}$ & 1.00 & & & & \\
\hline $\begin{array}{l}\text { Indoor air } \\
\text { RH }\end{array}$ & $\begin{array}{l}0.63 \\
0.000^{* *}\end{array}$ & 1.00 & & & \\
\hline $\begin{array}{l}\text { Indoor air } \\
\mathrm{PM}_{10}\end{array}$ & $\begin{array}{l}0.35 \\
0.000^{* *}\end{array}$ & $\begin{array}{l}0.34 \\
0.000\end{array}$ & 1.00 & & \\
\hline $\begin{array}{l}\text { Indoor air } \\
\text { TBC }\end{array}$ & $\begin{array}{l}0.60 \\
0.000^{* *}\end{array}$ & $\begin{array}{l}0.74 \\
0.000^{\text {*k }}\end{array}$ & $\begin{array}{l}0.47 \\
0.000^{* *}\end{array}$ & 1.00 & \\
\hline $\begin{array}{l}\text { Indoor air } \\
\text { TFC }\end{array}$ & $\begin{array}{l}0.59 \\
0.000^{* *}\end{array}$ & $\begin{array}{l}0.72 \\
0.000^{* *}\end{array}$ & $\begin{array}{l}0.50 \\
0.000^{\text {*k }}\end{array}$ & $\begin{array}{l}0.78 \\
0.000^{* *}\end{array}$ & 1.00 \\
\hline
\end{tabular}

Fig.1 Cumulative Mean indoor and outdoor temperature across the weeks 


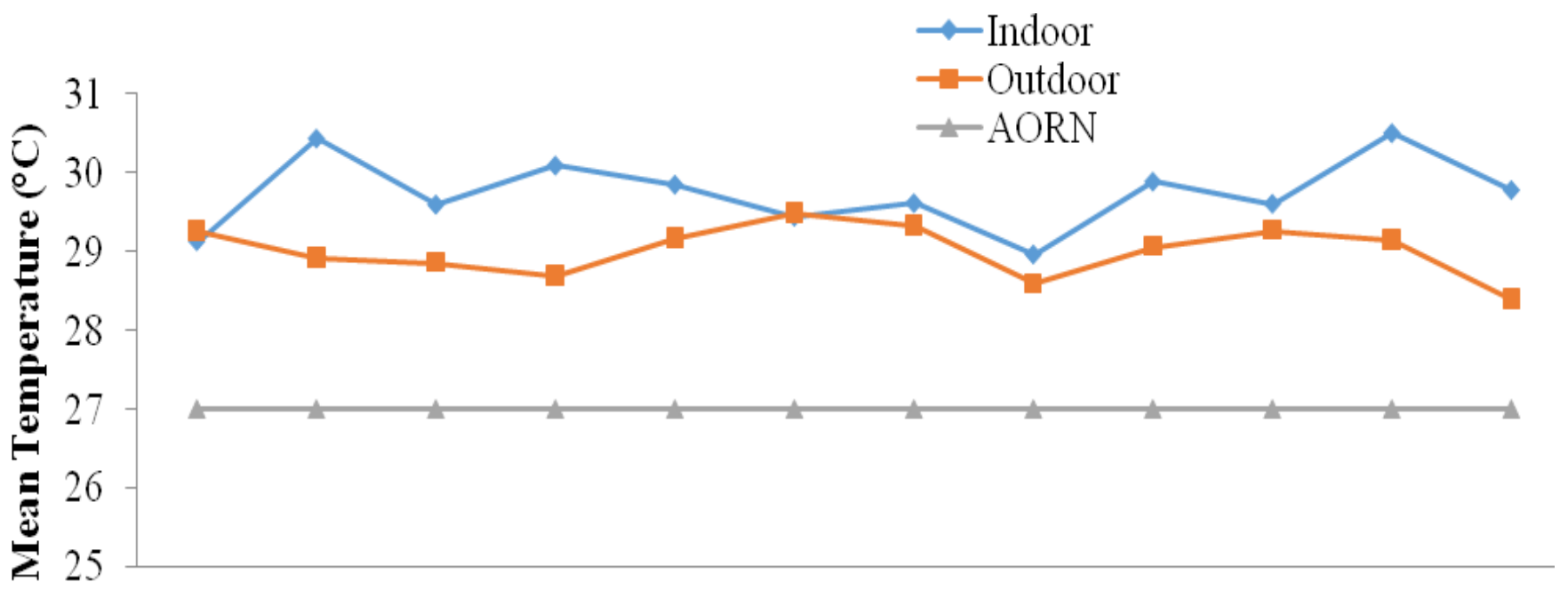

week 1 week 2 week 3 week 4 week 5 week 6 week 7 week 8 week 9 week week week

$\begin{array}{lll}10 & 11 & 12\end{array}$

\section{Weeks}

Fig.2 Cumulative Mean indoor and outdoor relative humidity across the weeks

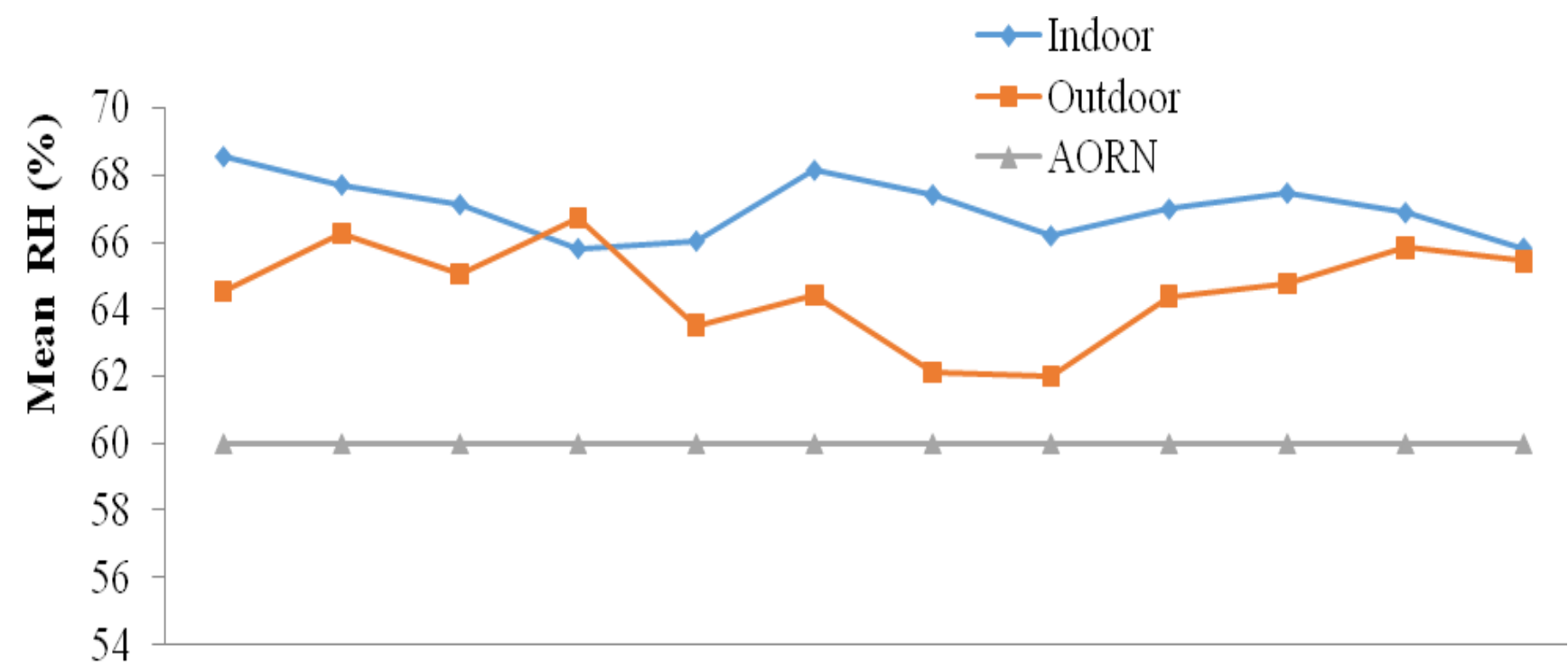

week 1 week 2 week 3 week 4 week 5 week 6 week 7 week 8 week 9 week week week Weeks

Fig.3 Cumulative mean indoor and outdoor particulate matter $\left(\mathrm{PM}_{10}\right)$ across the weeks 


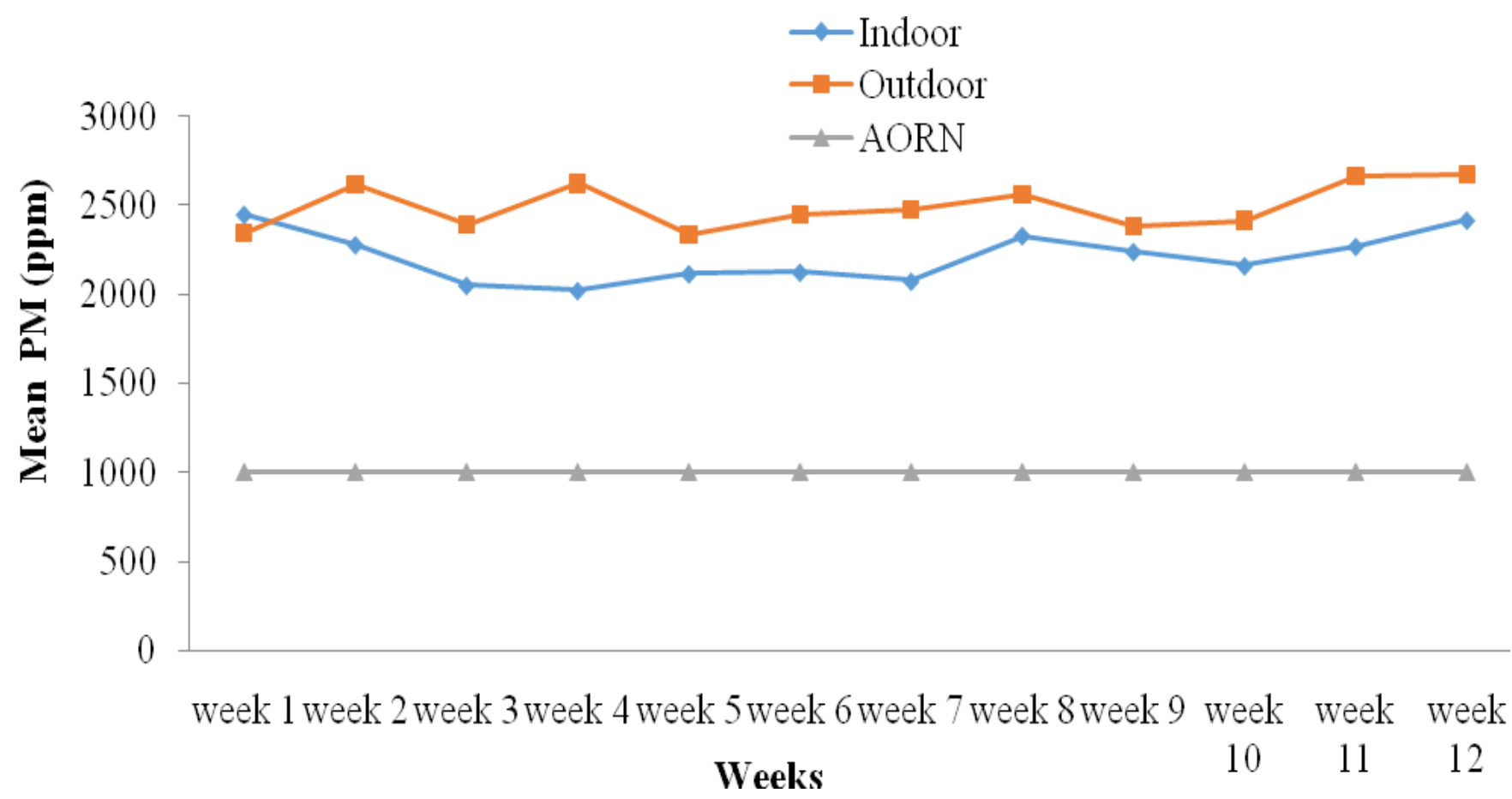

Fig.4 Mean indoor air TBC before and after surgery
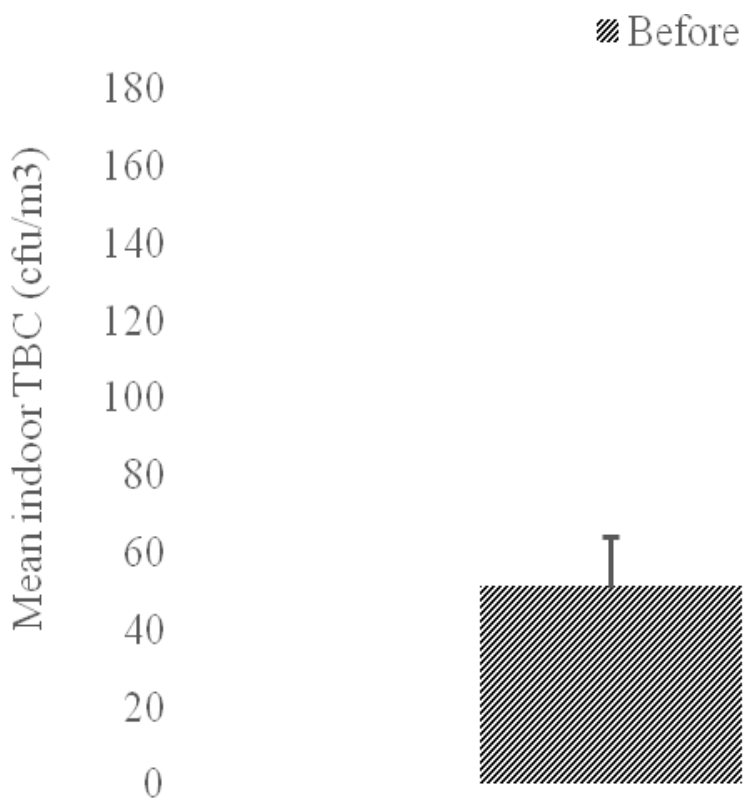

After

80

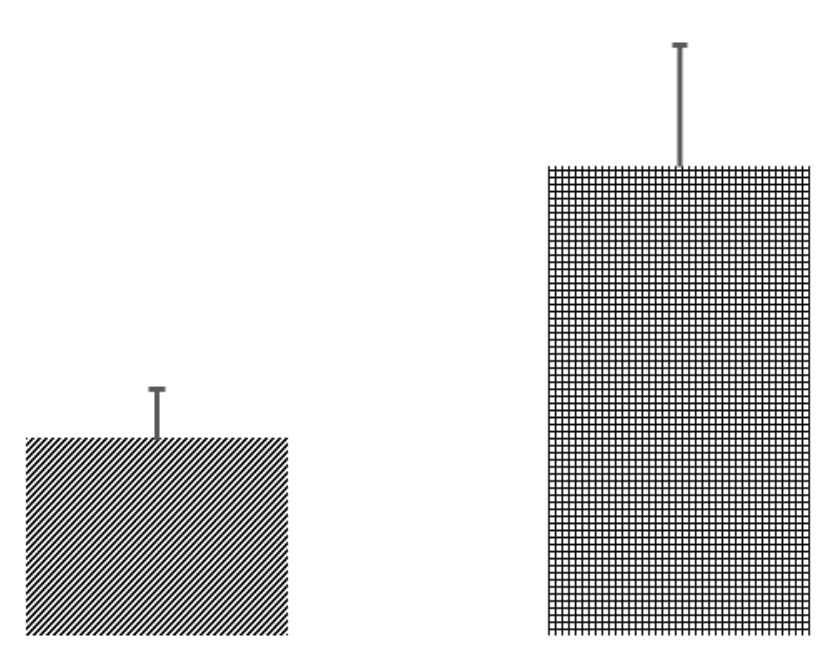

Sampling Point

Fig.5 Mean indoor air TFC before and after surgery 


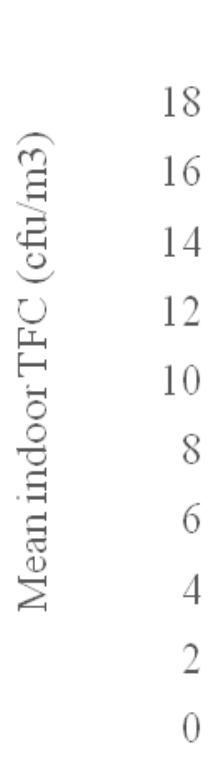

WB Before

8

6

4

2

0

6

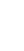

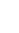

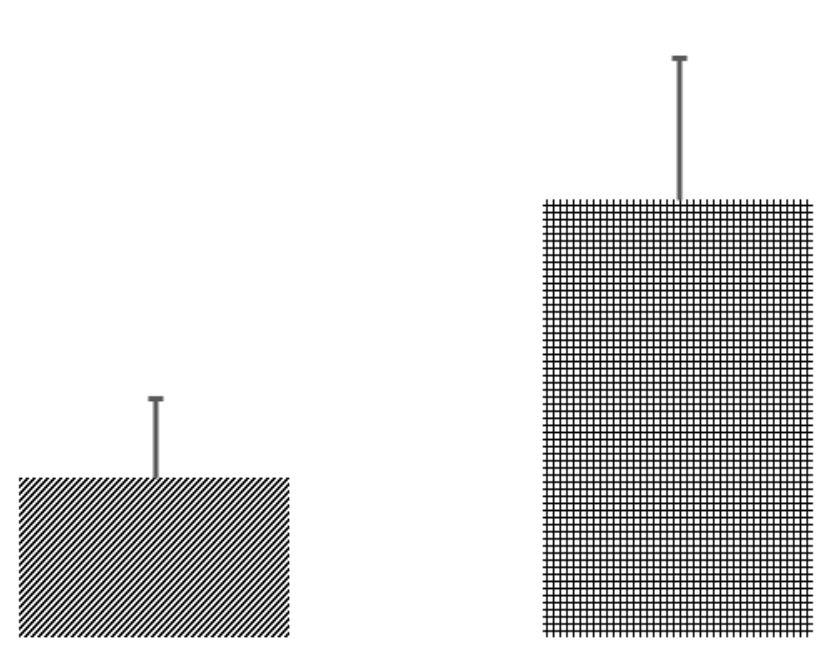

Sampling Points

Fig.6 Mean indoor air TBC of operating theatre before and after surgery across the theatre

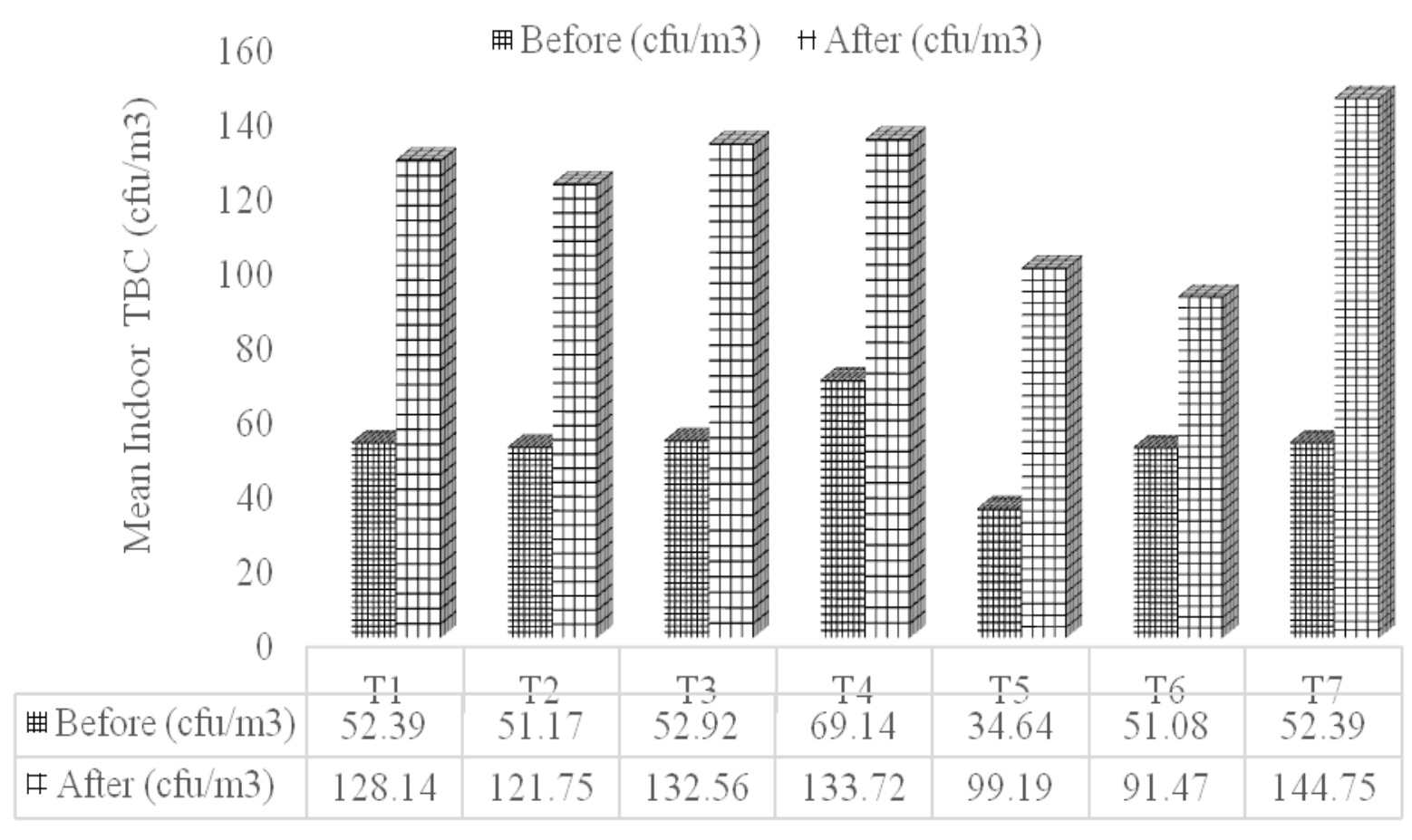

Operating Theatre

Fig.7 Mean indoor air TFC of operating theatre before and after surgery across the theatre 


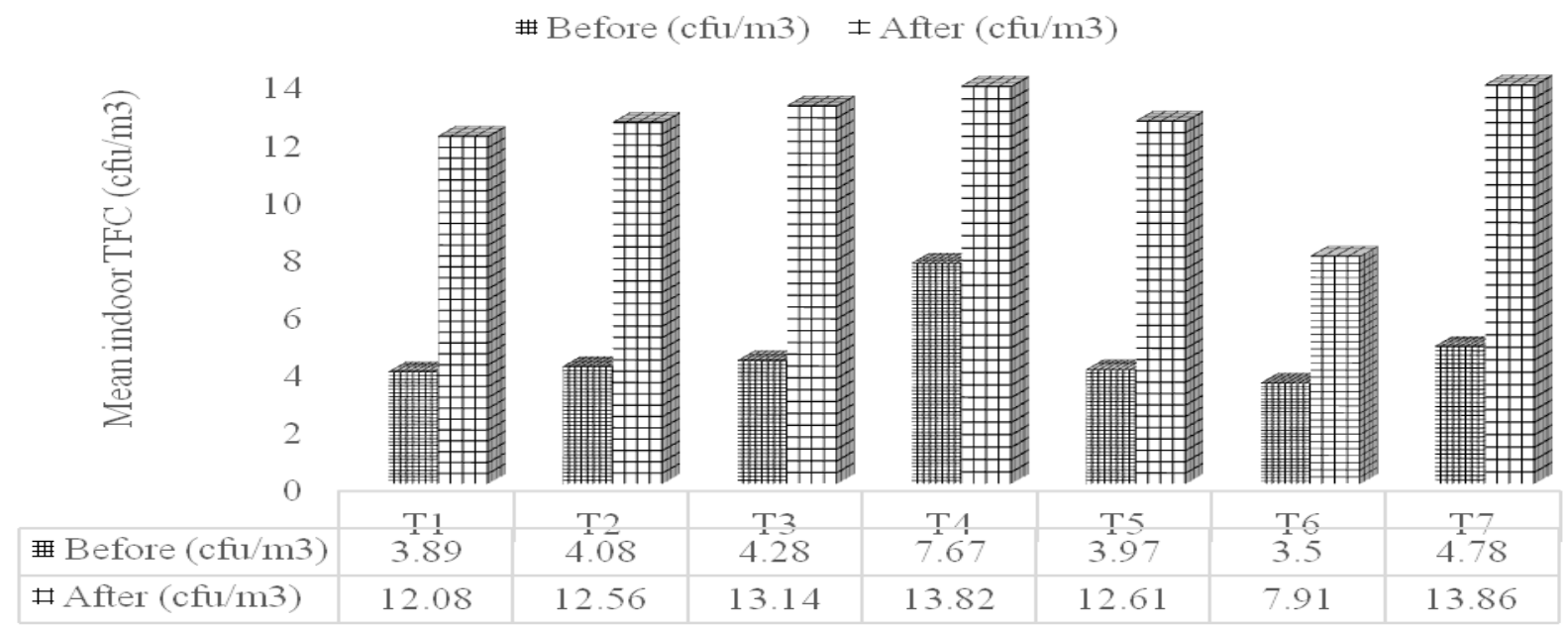

This was in contrast to a study carried out by Mahmoud and Mohamed (Mahmoud et al., 2014) who found the indoor temperature and relative humidity in an operating theatre to be within the acceptable range. The particulate matter $\left(\mathrm{PM}_{10}\right)$ concentration was higher after surgery than before surgery and the AORN recommended limit but lower when compared to outdoor concentrations.

This higher level could be attributed to the structure of the building, increased human traffic and activities inside the theatre. The hospitals is located near a busy road, thus motor vehicle exhaust, especially by poorly maintained and ageing automobiles might be a major cause of the elevated levels of $\mathrm{PM}_{10}$.

Airborne microbial contamination of air in the operating room is generally considered to be a major risk factor for post-surgical site infections in clean surgery (Landrin et al., 2005).According to Pasquarella et al., 2014, microbiological quality of air may be considered as mirror of the hygienic condition of the operation theatres. The quality of indoor air depends on external and internal sources, such as ventilation, cleaning procedures, the surgical team and their activity (Fleischer et al., 2005).In the present study, the indoor TBC and
TFC after surgery was significantly higher than the burden obtained before surgery. According to Fisher's index of microbial air contamination (Ekhaise et al., 2011), air microbial count of OT at rest and inactivity should not exceed 9.0 $\mathrm{cfu} / \mathrm{m}^{3}$ and $91.0 \mathrm{cfu} / \mathrm{m}^{3}$ respectively. However, the result obtained before and after surgery indicates airborne microbial contamination of the operating theatres. A similar study by Tewelde (Tewelde et al., 2015) found the airborne microbial load of an operating theatre at Northern Ethiopia to the higher than the Fisher's index.

Our findings also showed that the Emergency operating theatre (T7) recorded the highest bacteria burden before and after surgery. One of the reasons could be that $\mathrm{T} 7$ is the most commonly used operating theater. Individuals including hospital staff and patients' relatives are constantly active in this environment and according to Toivola (Toivola et al., 2002) airborne bacteria were dispersed into the air from crowded group of people. Therefore, the airborne microorganisms could be said to be of human origin. In similar terms, Bartlett et al., (2004) found that human inflow contribute to the rise in concentration of indoor airborne bacteria in a particular indoor environment and the concentration of the individual bacteria such as Micrococci and Staphylococci are related to 
the degree of occupancy or occupant activity.

The bacterial profile of indoor air samples showed that Staphylococcus spp. which is the most important cause of SSI (Kalliokoski, 2003) were the most frequently isolated species among other potential pathogenic bacteria identified in the operating theatres. The rate of isolation of Staphylococcus spp. was higher in the Emergency theatre than other operating theatres. Similarly, Aspergillus spp were the frequently isolated species of fungi among other pathogenic fungi isolated from the operating theatres. This variation may be due to difference in the presence of carriers (infected peoples) and in cleaning procedures that affect the load of the organisms in the air as it was suggested by Chikere (Chikere et al., 2008).

The mean indoor air TBC and TFC showed higher values when compared to standard (Ekhaise et al., 2011). Therefore, the present study implicated the indoor environment of the operating theatres after surgery as a major risk factor for surgical site infection. The findings from this study demonstrate that the microbiological quality of air in operation theatre may be considered a mirror image of the hygienic conditions of the operating theatre. A significant linear relationship was observed between indoor RH and TBC and TFC. Therefore, regular microbiological surveillance of the operating theatres is mandatory in reducing microbial contamination. Foot traffic in and out of the operating rooms should be reduced, the ventilation system should be improved and appropriate educational intervention on routine cleaning practices should be provided for sanitary personnel.

A major limitation of this study was the use of gravitational method to collect microbial samples from the operating theatres. This method only supports the growth of culturable organisms. Also, the inability to carry out molecular characterization of the different isolates is a major limitation of the study. Nevertheless, and to the best of our knowledge, the findings from this study would serve as the basis for future in-depth longitudinal study on airborne micro-floral assay in operating rooms and intensive care units to create a sterile environment for patients' care.

\section{References}

Al-Benna, S. 2012. Infection control in operating theatres. $J$ Perioper Pract; 22:318-322.

AORN. 2010. Recommended practices for preoperative patient skin antisepsis. Perioperative Standards and Recommended Practices. Denver: AORN; Inc.: 357.

AORN. Correct site surgery tool kit. Available at:

http://www.aorn.org/PracticeResources/T oolKits/.CorrectSiteSurgeryToolKit/Dow nloadTheCorrectSiteSurgeryToolKit/. Accessed August 10, 2016.

Bartlett, K. H., Kennedy S. M., Brauer M., Netten C. V. and Dill B. 2004. Evaluation and determinants of airborne bacterial concentrations in school classrooms. $J$ Occup Environ Hyg; 1: 639-647.

Chacko, L., Jose S., Isac A., Bhat K.G. 2003. Survival of nosocomial bacteria on hospital fabrics. Indian. J Med Microbiol; 21:291.

Chikere, B. C., Omoni T. V., Chikere O. B. (2008). Distribution of potential nosocomial pathogens in a hospital environment. Afr J Biotechnol.; 7:35353539.

Edmiston, C. E., Seabrook G. R., Cambria R. A., Brown K. R., Lewis B. D., Sommers J. R. 2005. Molecular epidemiology of microbial contamination in the operating room environment: Is there a risk for infection? Surgery; 138:573-579.

Ekhaise, O. F., Ighosewe U. O., Ajakpovi D. O. 2011. Hospital indoor airborne microflora in private and government owned hospitals in Benin City, Nigeria. World $J$ Med Sci.; 3:19-23.

Ensayel, S., Al-Shalchi, S., and Sabbar, M. 2009. Microbial contamination in the operating theatre: a study in a hospital in 
Baghdad, Eastern Mediterranean Health J.; 15(1):219-223.

Fleischer, M., Bober-Gheek, B., Bortkiewicz, O., Rusiecka-Ziolkowska, J. 2005.Microbiological Control of Airborne Contamination in Hospitals. Indoor built environ; 15: 153-6.

Godish, T., Boca Raton. 4th ed. Florida: Lewis Publishers; 2003. Air quality

Holt, J. G., Krieg N. R., Sneth P. H., Stanley J. T. and Williams S. T. 1994. Bergey's manual of determinative bacteriology, 9th ed. Baltimore, MD: Williams and Wilkins.

Kalliokoski, P., 2003. Risks Caused by Airborne Microbes in Hospitals - Source Control is Important. Indoor Built Environ; 12:41-46.

Landrin, A., Bissery A. and Kac G. 2005. Monitoring air sampling in operating theatres: can particle counting replace microbiological sampling? J Hosp Infect.; 61 (1): 27-9.

Mahmoud, F. E., and Mohamed E. H. 2014. Indoor air quality levels in a University Hospital in the Eastern Province of Saudi Arabia. J Family Community Med; 21(1): 39-47.

Mentes, A., de Koning L., Shannon H. S. and Anand S. S. 2009. A systematic review of the evidence supporting a causal link between dietary factors and coronary heart disease. Arch Intern Med.; 169(7): 659-669

Nwankwo, E. O., Azeez O. A. 2015. Microbial Contamination in the Operating Theatre of a Tertiary Health Institution InKano, Northwestern Nigeria. Nigerian Journal of Microbiology; 27(1): 2671-2679
Odimayo, M. S., Nwabuisi, S., Agegbora, B. 2008. Hospital acquired infections in Illorin, Nigeria. Trop. J. Hlt. Sci.; 15: 49 51.

Okon, K.O., Osundi S., Dibal J., Ngbale T., Bello M., Akuhwa R.T. 2012. Bacterial contamination of operating theatre and other specialized care unit in a tertiary hospital in Northeastern Nigeria. Afr $J$ Microbiol Res.; 6:3092-3096.

Pasquarella, C., Masia M. D., Nnanga N., Sansebastiano G. E., Savino A., Signorelli C., Veronesi L. 2014. Microbial air monitoring in operating theatre: active and passive samplings. Ann Ig.; 16 (1-2): 375-86.

Polish Standard 89/Z-04008/08. Air purity protection. Microbiological testing. Determination number of the fungi in the atmospheric air (imision) with sampling by sedimentation method.

Prigane, V., Lingua, G., Marchisco, V. F. 2004. Development and use of flow cytometry detection of airborne fungi. App. Env. Microb; 70: 13601365.

Reddy, B.R., 2012. Management of culturenegative surgical site infections. J Med Allied Sc.; 2:2-6.

Tewelde, T., Yibrah B., Kibrom G. 2015. Microbial contamination of operating Theatre at Ayder Referral Hospital, Northern Ethiopia. International Journal of Pharma Sciences and Research (IJPSR); 6:1264 - 1267

Toivola, A. M., Alm S., Reponen T., Kolari S., Nevalainen A. 2002. Personal exposures and micro-environmental concentrations of particles and bioaerosols. J Environ Monit; 4: 166.

\section{How to cite this article:}

Ogundare Johnson O., G. Fakunle Adekunle, Alege Adenike, T. Soyemi Elizabeth, M. Ezinne Sylvia and Bolaji Olayinka M. 2017. Indoor Airborne Microbial Burden of Operating Theatres in a Tertiary Hospital in South-Western Nigeria. Int.J.Curr.Microbiol.App.Sci. 6(9): 3335-3345. doi: https://doi.org/10.20546/ijcmas.2017.609.412 